\title{
Toxicity Associated with Repeated Administration of First-Generation Adenovirus Vectors Does Not Occur with a Helper-Dependent Vector
}

\author{
Wanda K. O'Neal, ${ }^{1,4}$ Heshan Zhou, ${ }^{1}$ Núria Morral, ${ }^{1}$ Claire Langston, ${ }^{2}$ \\ Robin J. Parks, ${ }^{4}$ Frank L. Graham, ${ }^{4}$ Stefan Kochanek ${ }^{1}$ and Arthur L. Beaudet ${ }^{1}$ \\ ${ }^{1}$ Department of Molecular and Human Genetics, Baylor College of Medicine, \\ Houston, TX, U.S.A. \\ ${ }^{2}$ Department of Pathology, Baylor College of Medicine, Houston, TX, U.S.A. \\ ${ }^{3}$ Departments of Biology and Pathology, McMaster University, Hamilton, \\ Ontario, Canada \\ ${ }^{4}$ Present address: Cystic Fibrosis/Pulmonary Research and Treatment Center, \\ University of North Carolina at Chapel Hill, Chapel Hill, NC, U.S.A.
}

Accepted November 29, 1999.

\begin{abstract}
Background: Certain gene therapy protocols may require multiple administrations of vectors to achieve therapeutic benefit to the patient. This may be especially relevant for vectors such as adenoviral vectors that do not integrate into the host chromosome. Because immunocompetent animal models used for gene transfer studies develop neutralizing antibodies to adenoviral vectors after a single administration, little is known about how repeat administrations of vectors might affect transgene expression and vector toxicity. Materials and Methods: We used mice deficient in the membrane spanning region of immunoglobulin (IgM), which do not develop antibodies, to evaluate the effect of repeated intravenous administration of first-generation and helper-dependent adenoviral vectors expressing human $\alpha_{1}$-antitrypsin (hAAT). The duration and levels of transgene expression were evaluated after repeated administration of vectors. Toxicity was assessed by measuring the level of liver enzymes in the serum and the degrees of hepatocyte hypertrophy and proliferation.
\end{abstract}

Results: We found that previous administration of first-generation adenoviral vectors can alter the response to subsequent doses. These alterations included an increase in transgene expression early (within 1 and 3 days), followed by a rapid drop in expression by day 7. In addition, previous administrations of first-generation vectors led to an increase in toxicity of subsequent doses, as indicated by a rise in liver enzymes and an increase in hepatocyte proliferation. In contrast to first-generation vectors, use of the helper-dependent adenovirus vector, AdSTK109, which contained no viral coding regions, did not lead to increased toxicity after multiple administrations.

Conclusions: We conclude that the response of the host to adenoviral vectors can be altered after repeated administration, compared with the response after the initial vector dose. In addition, these experiments provide further evidence for the relative safety of helper-dependent adenoviral vectors for gene therapy, compared with first-generation vectors.
Address correspondence and reprint requests to: W. K. O'Neal, Ph.D., The University of North Carolina at Chapel Hill, Cystic Fibrosis/Pulmonary Research and Treatment Center, 7011 Thurston-Bowles Building, CB\# 7248, Chapel Hill, North Carolina 27599-7248, U.S.A. Phone: (919) 962-9866; Fax: (919) 966-682 1; E-mail:

woneal@email.unc.edu

\section{Introduction}

Adenoviral vectors are being evaluated for use in somatic gene therapy for the treatment of a variety of human diseases. Consequently, extensive information is now available regarding the host response to these vectors, especially in rodents 
and primates. First-generation adenoviral vectors, which carry a deletion in the adenovirus El region but contain most of the other adenovirus genes, have been studied most thoroughly (1-3). It is known that immunocompetent animals can mount an aggressive immune response against these vectors and that response can take multiple forms. Production of neutralizing antibodies against the vector can block the ability to achieve expression when the vectors are readministered (4-6). Development of cytotoxic T lymphocyte (CTL) responses to viral proteins and the resultant destruction of infected cells is reported to be an important determinant of duration of expression (7-10). In addition, humoral or cellular immune responses to transgenic proteins can limit duration of expression (11-15). Finally, adenoviral vectors also can be directly toxic to cells in a dose-dependent manner independent of host Band T-cell responses $(11,12,16-19)$.

Second-generation adenoviral vectors have been developed that contain more extensive deletions of the adenovirus backbone (i.e., deletions in E2a or E4), following the rationale that decreased expression of viral genes will reduce any direct toxity of these genes and decrease the potential for immune response to newly synthesized viral proteins (20-29). Because most immunocompetent animal models will develop a host immune response to foreign reporter genes at either the level of antibody production against a secreted protein or CTL responses against transduced cells, it has been relatively difficult to evaluate the effect of altering the vector design on the duration of expression and toxicity. Second-generation vectors are reported to provide benefits in terms of duration of expression and toxicity in vivo $(23,24,28,30-33)$; however, the benefits are often limited and some reports suggest little or no advantage to vectors deleted in E2a or E4 when evaluated in the current models (12,34-36). Recently, it was demonstrated that helper-dependent adenoviral vectors (also called high-capacity or "gutless" vectors) containing no adenovirus coding sequences can lead to long-term expression of the transgene, seemingly by reducing immune responses to viral proteins and by decreasing the direct toxicity caused by expression of viral genes (16,37-40). Thus, the helper-dependent vectors show great promise for use in the clinical setting. However, animals injected with these vectors still develop neutralizing antibodies ( $\mathrm{N}$. Morral, unpublished), which would continue to be a serious limitation for many applications.

For many conditions, even if expression does not decline in target cells infected during the initial administration, natural cell turnover would require that the vector be administered at regular intervals to maintain therapeutic levels of a protein. Although the development of neutralizing antibodies is a serious limitation at the present time, it may be possible to achieve effective readministration of adenoviral vectors by pharmacologic immunosuppression. This was demonstrated in animal models (41-47) by using vectors of differing serotypes to avoid the effects of the neutralizing antibodies $(48-50)$ or by the induction of tolerance $(11,51,52)$. However, even in the absence of neutralizing antibodies, it remains possible that established immune responses, particularly cellular responses to viral proteins, could limit expression from transgenes with subsequent doses in previously treated individuals.

In the experiments reported here, mice deficient in the membrane-spanning domain of IgM (designated $\mu \mathrm{MT}$ ) (53), were used as a model to assess the effect of multiple administration of vectors on transgene expression in the presence of functioning $\mathrm{T}$ cells. These mice are devoid of B cells but are normal with respect to other immune functions including T-cell functions (54). We demonstrated that previous doses of firstgeneration vectors increased the toxicity of subsequent doses and altered the expression kinetics of transgenes. We further demonstrated that multiple doses of a helper-dependent vector, AdSTK109, did not lead to increased toxicity with subsequent administration, in contrast to the results with first-generation vectors, suggesting a further advantage of this type of vector for gene therapy.

\section{Materials and Methods}

Vectors

The vectors used and their characteristics are described in Table 1. AdJM17 $\mathrm{E}$ l was constructed by homologous recombination between pJMI7 (55) and pXCJL.2 in 293 cells. AdJM17DEl contains an El deletion, but no transgene. Constructions of all other vectors have been or will be reported elsewhere (see Table 1). Firstgeneration adenoviral vectors were grown by standard protocols in 293 cells and purified by $\mathrm{CsCl}$ centrifugation $(56,57)$ either in the re- 
Table 1. Vectors used and their characteristics

\begin{tabular}{|c|c|c|c|}
\hline Vector Type & $\begin{array}{l}\text { Deleted Viral } \\
\text { Genes }\end{array}$ & $\begin{array}{l}\text { Vector Name } \\
\text { (Abbreviation) }\end{array}$ & Vector Characteristics \\
\hline First-generation & E1, E3 (dl309) & AdJM17 $\Delta \mathrm{E} 1$ & $\begin{array}{l}\text { Contains no transgene, based upon adenoviral } \\
\text { vector pJM17 (55) (see methods) }\end{array}$ \\
\hline First-generation & El & $\operatorname{AdhAAT} \Delta \mathrm{E} \mathbf{l}$ & $\begin{array}{l}\text { Phosphoglycerate kinase promoter driving ex- } \\
\text { pression of human } \alpha_{1} \text {-antitrypsin (hAAT) } \\
\text { (29); based upon adenoviral vector } \\
\text { pBHGE3 (78) }\end{array}$ \\
\hline First-generation & E1, E3 & $\operatorname{AdhAFP} \Delta \mathrm{E} 1 \mathrm{E} 3$ & $\begin{array}{l}\text { CAG promoter }(79,80) \text { driving expression of } \\
\text { human } \alpha \text {-fetoprotein (hAFP) (W. O'Neal, } \\
\text { unpublished). Based upon adenoviral } \\
\text { vector pBHG10 (78) }\end{array}$ \\
\hline First-generation & El & $\operatorname{Ad} \beta \operatorname{gal} \Delta \mathrm{El}$ & $\begin{array}{l}\text { Expresses nuclear-targeted } \beta \text {-galactosidase; } \\
\text { (29) CMV promoter; based upon adenoviral } \\
\text { vector pBHGE3 (78) }\end{array}$ \\
\hline Helper-dependent & All & AdSTK 109 & $\begin{array}{l}\text { Contains endogenous hAAT gene, including } \\
\text { promoter region (37) }\end{array}$ \\
\hline
\end{tabular}

search laboratory or by the Gene Vector Production Core Laboratory at Baylor College of Medicine (Houston, TX). The helper-dependent vector, AdSTK 109, was produced in 293Cre4 cells (58) at McMaster University (Ontario, Canada), as described previously (59). Particles $/ \mathrm{ml}$ were determined by optical density and plaqueforming units (PFU) titers of first-generation vectors were determined on 293 cells as described (60).

\section{Mice and Mouse Injections}

All mice were obtained originally from The Jackson Laboratories (Bar Harbor, ME) and were at least 8 weeks old before injection. B-cell-deficient mice, homozygous for a deletion in IgM $(\mu \mathrm{MT})$ (53), and B- and T-celldeficient mice, homozygous for a deletion of the recombination activation gene (Rag-1) (61) were bred in the Baylor College of Medicine vivarium. Both mutations were on a $\mathrm{C} 57 \mathrm{BL} / 6 \mathrm{~J}$ background, thus, $\mathrm{C} 57 \mathrm{BL} / 6 \mathrm{~J}$ mice were used as immunocompetent control animals. The number of mice used for each experiment is indicated in Figures 1-3. Vector injections were via tail vein using $200 \mu \mathrm{l}$ of vector per mouse, diluted in phosphate-buffered saline (PBS) to give the appropriate dose. Doses and injection schedules for each experiment are indicated in figure legends. Serum was obtained by retroorbital bleeding, followed by two centrifugations at $7000 \mathrm{rpm}$ for 5 minutes. Serum was frozen at $-80^{\circ} \mathrm{C}$ until analysis.

\section{Evaluation of Gene Expression and Toxicity}

Levels of hAAT in serum were determined by ELISA assay, as previously described (62). Expression of $\beta$-gal in the liver was determined as described $(12,63)$. Levels of liver enzymes alanine aminotransferase (ALT), aspartate aminotransferase (AST) and alkaline phosphatase (AP) were determined from serum by the Clinical Pathology Laboratory of the Department of Comparative Medicine at Baylor College of Medicine. Immunohistochemistry and hematoxylin/eosin (H/E) staining were performed on paraffin-embedded tissues fixed in $10 \%$ formalin. The number of proliferating cells was evaluated, as previously described (16), by immunohistochemistry to Ki-67 antigen, a marker for cell proliferation $(64,65)$. The relative degree of proliferation among samples was determined by counting the total number of Ki-67 positive hepatocytes in 10 randomly selected, high power ( $40 \times$ objective) fields. Hepatocyte hypertrophy was determined by counting hepatocyte nuclei present in 7 randomly selected fields of a reticle (reticle area $=0.0156 \mathrm{~mm}^{2}$ ).

\section{Data Analysis and Statistics}

All error bars shown are standard deviations. Statistical analysis was conducted on the Statview $^{\circledR}$ (Abascus Concepts, Berkeley, CA) or SigmaStat ${ }^{\circledR}$ (Jandel Scientific, San Rafael, CA) statistical analysis software. Means were compared as indicated in the figure legends. 


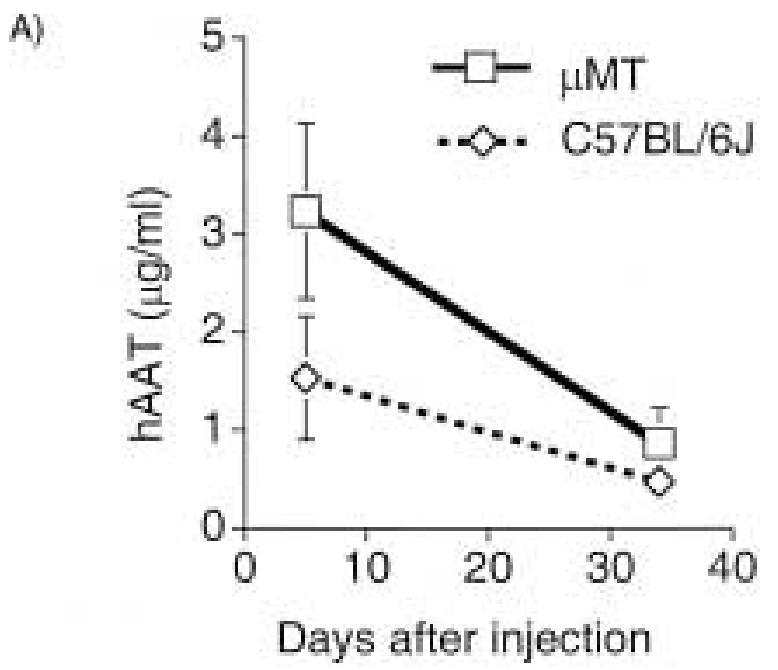

B)

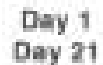

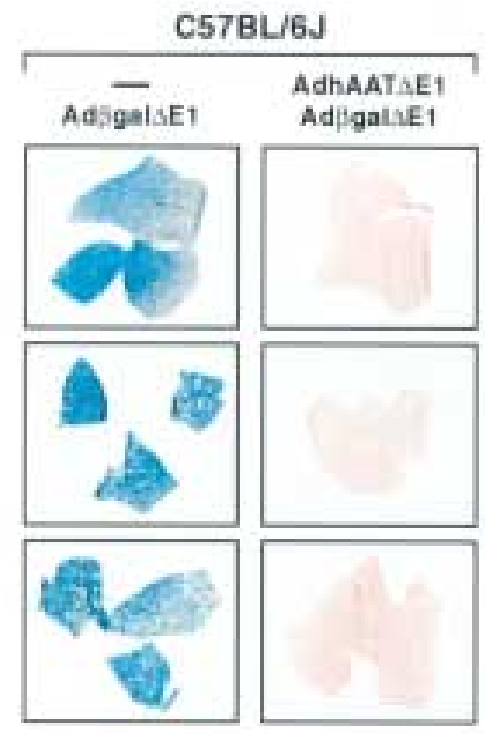

Fig. 1. Increased transgene expression in $\mu M T$ mice and repeated dosing of adenoviral vectors in $\mu M T$ and C57BL/6J mice. (A) hAAT levels in $\mu \mathrm{MT}$ and control C57BL/6J mice at 5 and 19 days after initial intravenous administration of AdhAAT $\Delta \mathrm{E} 1$ at a dose of $2 \times 10^{9} \mathrm{PFU} / \mathrm{mouse}$ $\left(4.4 \times 10^{10}\right.$ particles); $n=5$ for each group. (B) Histological sections from livers of C57BL/6J and $\mu \mathrm{MT}$ mice treated at day 1 with either no vec-

\section{Results}

\section{Readministration is Possible in $\mu M T$ Mice}

To evaluate whether or not $\mu \mathrm{MT}$ mice could be used to study readministration, five $\mu \mathrm{MT}$ and five C57BL/6J control mice were injected with $2 \times 10^{9}$ PFU of AdhAAT $\Delta$ El $\left(4.4 \times 10^{10}\right.$ particles). Levels of hAAT expression in the serum were determined at 5 and 34 days after administration (Fig. 1A). In this experiment, levels of

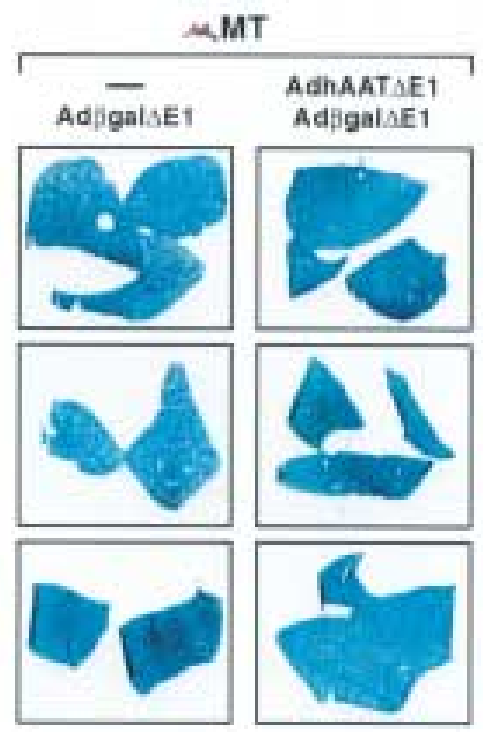

tor or with AdhAAT $\Delta \mathrm{E} 1$, as described in Fig. 1A and then treated on day 21 with $\operatorname{Ad} \beta g a l \Delta E 1$ at $3 \times 10^{9}$ PFU/mouse $\left(3 \times 10^{10}\right.$ particles $)$. Blue staining indicates color development dependent upon the presence of the $\beta$-galactosidase transgene. Animals were sacrificed 3 days after $\operatorname{Ad} \beta$ gal $\Delta E 1$ injection. Representative samples from 3 mice in each group are shown at low magnification.

hAAT expression at 5 days after administration were 2-fold higher in $\mu \mathrm{MT}$ mice, compared with control mice $(p=<0.02)$. The increased transgene expression seen in $\mu \mathrm{MT}$ mice in this particular study was similar to results described previously with other immunodeficient mice, including Rag-1 and scid $(37,66)$. The reason for increased transgene expression in immunodeficient mice, compared with immunocompetent mice in some experiments, is not clear. This dif- 


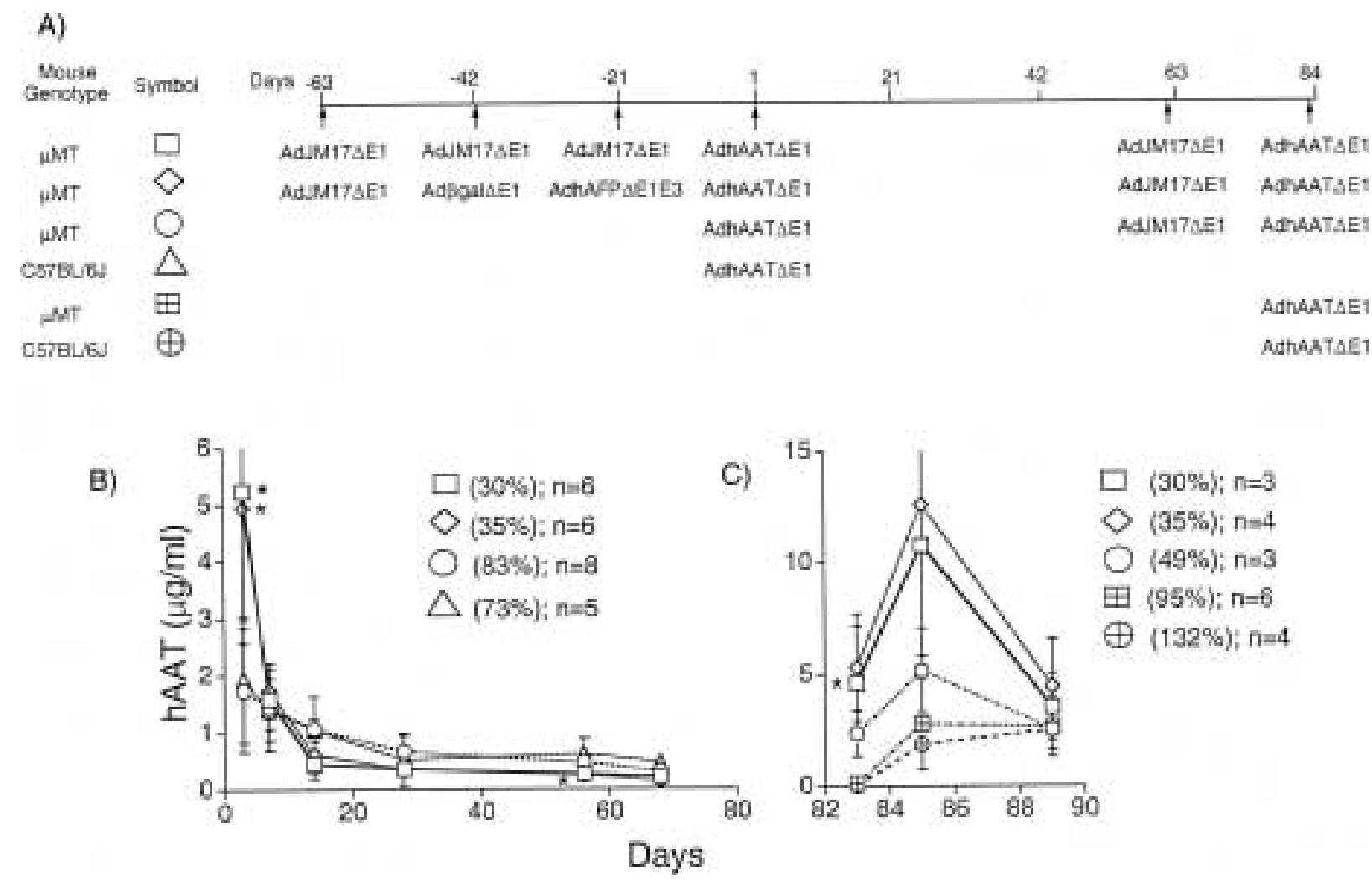

Fig. 2. Altered transgene expression following repeated administration of first generation adenoviral vectors. (A) The experimental protocol used for the experiments described in Figure 2B and $2 \mathrm{C}$. The mouse genotypes and the symbol associated with each treatment group are indicated to the left. Days are indicated on the timeline. Arrows indicate the days of vector administration. The vectors administered for each treatment group are listed below the arrows. All vector doses were $1 \times$ $10^{9}$ PFU/animal $\left(2 \times 10^{10}, 8 \times 10^{9}, 3 \times 10^{10}\right.$, and $8 \times 10^{10}$ particles/animal for AdhAAT $\Delta E 1$, $\operatorname{Ad} \beta$ gal $\Delta \mathrm{E} 1, \operatorname{AdJM} 17 \Delta \mathrm{E} 1$, and AdhAFP $\Delta \mathrm{E} 1 \mathrm{E} 3$, respectively). (B) Levels of hAAT after the dose of AdhAAT $\Delta$ El that was administered on day 1 . Treatment groups correspond to those of Figure $2 \mathrm{~A}$. Next to each treatment group symbol is listed the percentage of hAAT expression at day 7 (in parentheses) compared with the initial day 3 value. The

ference was not observed in all studies (see Fig. 3). Three weeks after the initial injection, the pretreated and naive $\mu \mathrm{MT}$ and control mice were reinjected with the $\mathrm{Ad} \beta \operatorname{ggal} \Delta \mathrm{El}$ vector at a dose of $3 \times 10^{9} \mathrm{pfu} / \mathrm{mouse}$. The mice were sacrificed after 7 days for evaluation of hepatic expression of $\beta$-gal expression. Expression of $\beta$ gal was detected in the pretreated and naive $\mu \mathrm{MT}$ mice and in naive C57BL/6J control mice, but was not detected in the $\mathrm{C} 57 \mathrm{BL} / 6 \mathrm{~J}$ mice that were previously injected with $\operatorname{AdhAAT} \Delta \mathrm{El}$ (Fig. 1B). Analogous results were obtained number of animals (n) for each group at the start of the separate experiments is also listed. For each separate time point, significant differences among the groups receiving multiple injections and the mice receiving a single injection are indicated by an asterisk $(*)$. The statistical test was a one-way analysis of variance $(p=0.05)$ with correction for multiple comparisons (Student-Newman-Keuls method). When the normality or equal variance tests failed, the comparison was conducted using the Kruskal-Wallis one-way analysis of variance on ranks with the Dunn procedure for pairwise multiple comparisons. (C) Levels of hAAT levels after the second administration of AdhAAT $\Delta E 1$ (day 82). Percentages and n-values are listed as described in Figure 2B. For both Figures 2B and 2C, error bars depict the standard deviation. Note the change in scale for both the $\mathrm{X}$ and $\mathrm{Y}$ axes between Figures $2 \mathrm{~B}$ and 2C. Statistics are as described for Figure 2B.

when the $\beta$-gal vector was given first $\left(2 \times 10^{9}\right.$ pfu/mouse), followed by AdhAAT $\Delta \mathrm{El}\left(2 \times 10^{9}\right.$ pfu/mouse); hAAT was expressed in naive and $\operatorname{Ad} \beta$ gal $\Delta \mathrm{El}$-pretreated $\mu \mathrm{MT}$ mice, but not in C57BL/6J mice previously treated with $\operatorname{Ad} \beta \operatorname{gal} \Delta \mathrm{El}$ (data not shown). These results indicated that the absence of B-cell-mediated immunity in $\mu \mathrm{MT}$ mice allowed for transgene expression from adenoviral vectors in mice previously exposed to vectors, presumably due to lack of neutralizing antibodies. The ability to successfully achieve expression after previous 


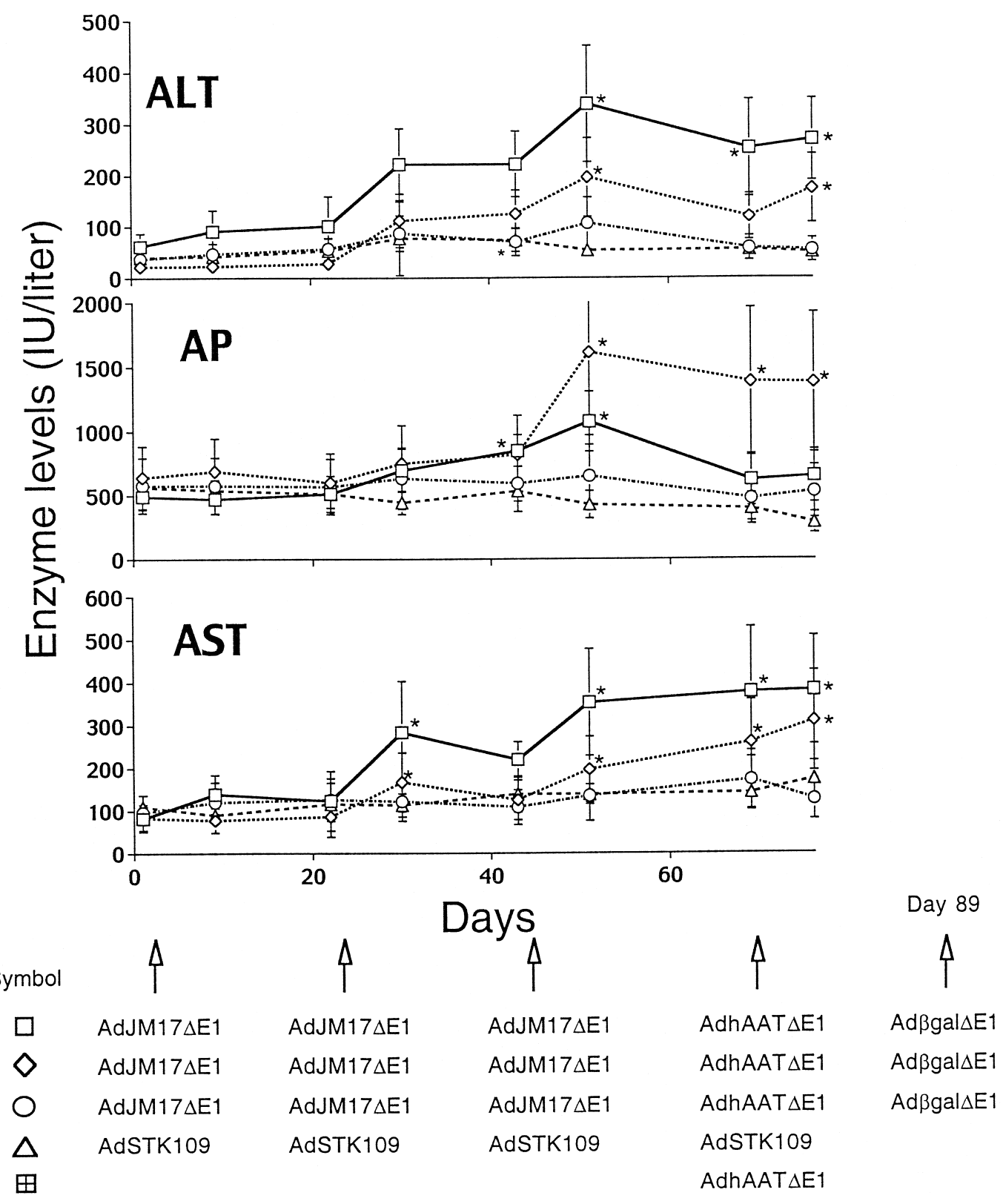

A)
Mouse

Genotype (n)

$\mu \mathrm{MT}(6)$

$\operatorname{Rag}-1(3)$

C57BL/6J (3)

$\mu \mathrm{MT}(7)$

$\mu \mathrm{MT}(6)$
Fig. 3. Analysis of toxicity and transgene expression following repeated dosage of first generation and helper-dependent adenoviral vectors. (A) Increased hepatotoxicity following repeated doses of first-generation but not helperdependent adenoviral vectors, as measured by liver enzyme levels. The experimental protocol for Figure 3 experiments is outlined below the graphs. Mouse genotypes along with their corresponding symbols and vector treatments are listed. Arrows indicate the time of vector delivery. The vectors delivered are shown below the arrows. Liver enzyme (ALT, AP, and AST) analysis for serum drawn at different times for each group of experimental animals. ALT $=$ alanine aminotransferase; AP = alkaline phosphatase; AST = aspartate aminotransferase. Times of harvest of serum for liver enzyme analysis (always 1 day prior and 7 days subsequent to each vector injection indicated by arrows). The vectors used for each injection are indicated below the large arrows. All first generation vectors (AdJM17 $\Delta \mathrm{E} 1$, AdhAAT $\Delta \mathrm{E} 1$, and $\operatorname{Ad} \beta \operatorname{gal} \Delta \mathrm{E} 1$ ) were given by tail vein injection at $1 \times 10^{9} \mathrm{PFU} / \mathrm{mouse}$. AdSTK 109 was administered by tail vein injection at $2 \times 10^{10}$ particles/mouse. Significant increases in enzyme levels above pretreatment values for each group of animals are indicated by asterisks $\left({ }^{*}\right)$. The statistical method used was a one-way analysis of variance with the Bonferroni method to compare post-treatment values with pretreatment values. The Kruskal-Wallis one-way analysis of variance on ranks procedure was used when normality or equal variance tests failed, in which case, values were compared with pretreatment values using the Dunn method. (B) Levels of hAAT for groups of mice receiving first-generation vectors. The data are from the same mice shown in Figure 3A. Day 0 in panel 3B corresponds to day 68 in panel $3 \mathrm{~A}$, which 


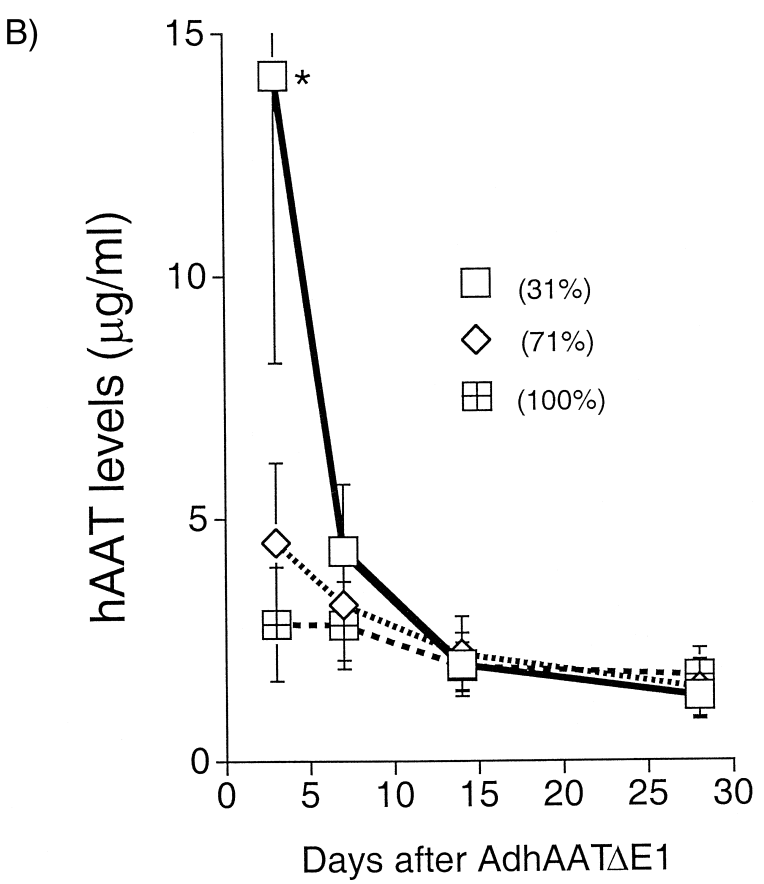

corresponds to the day of administration of the vector AdhAAT $\Delta \mathrm{E}$. Symbols shown correspond to mice and treatments as in panel $3 \mathrm{~A}$. The asterisk indicates a significant difference from the control group receiving only one dose of vector. Statistical analysis was as in Figure $2 \mathrm{~B}$. The percent expression on day 7 , compared with day 3 is shown in parenthesis, as described in Figure 2B. (C) Evaluation of hepatocyte proliferation, as determined by Ki-67 staining (top panel), and hepatocyte hypertrophy, as determined by counting nuclei within a given area (bottom panel; as the degree of hypertrophy increases, the number of hepatocytes per field decreases). The mice are the same animals as described in Figure 3A, except for a new group of naive $\mu \mathrm{MT}$ mice receiving one dose of $\operatorname{Ad} \beta \operatorname{gal} \Delta \mathrm{El}$ (seen in the fourth bar in the graphs). The mouse strains and the vectors used for each group are given below the columns. The number of times the animals received each vector is indicated by " $X$ ". The number of Ki-67 positive hepatocytes was determined by counting Ki-67 positive nuclei in 10 high power $(40 \times$ objective) fields. The number of hepatocytes per field was determined by counting nuclei in seven fields of a reticle that has an area of $0.0156 \mathrm{~mm}^{2}$. All mice were sacrificed 3 days after

vector exposure in $\mu \mathrm{MT}$ mice indicated that these mice would be a useful model to study repeated administration.

\section{Readministration Leads to Altered Expression} Kinetics with First-Generation Vectors

The effects of repeated administration of a vector on duration of expression were evaluated by injection of $\mu \mathrm{MT}$ and C57BL/6J mice with the final vector dose indicated in Figure 3A. Horizontal bars with an asterisk indicate values that were significantly different using one-way analysis of variance $(p=0.5)$ and the Student-NewmanKeuls method for multiple comparisons. (D) Levels of hAAT for $\mu \mathrm{MT}$ mice injected with AdSTK 109. Mice and treatments are the same as described in Figure 3A for the group receiving AdSTK109. Arrows indicate time of vector administration. Error bars indicate standard deviation for all graphs in Figure 3. (E) Photomicrographs of heptocytes showing cell proliferation and hypertrophy after treatment with first-generation, but not helperdependent vector. Panels $1-4$ are hematoxylin and eosin stained sections (H \& E) and panels 5-8 are stained for the cell proliferation marker Ki-67. Mouse genotypes and vector treatments are indicated below the panels. The group symbol corresponds to the groups as described in Figure $3 \mathrm{~A}$. All pictures are the same magnification and were originally taken at $400 \times$. Examples of Ki-67 positive hepatocytes are indicated by small arrows in panels 6 and 7. Proliferating hepatocytes are not present in panels 5 and 8 . The other positive cells seen in the Ki-67 stain are proliferating immune cells.

Fig. 3. Continued on next page.

multiple vectors at 3-week intervals, followed by a final dose of AdhAAT $\Delta E 1$, as shown in Figure 2A. One group of $\mu \mathrm{MT}$ mice received three doses of a reporterless vector (AdJM17 $\triangle \mathrm{E} 1$ ) followed by the hAAT vector. Another group of $\mu \mathrm{MT}$ mice received three different vectors (AdJM17 $\Delta \mathrm{El}$; $\mathrm{Ad} \beta \mathrm{gal} \Delta \mathrm{El}$; and AdhAFP $\Delta$ ElE3, expressing human $\alpha$-fetoprotein), followed by the hAAT vector. hAAT levels in these two groups of mice were compared with 
C)

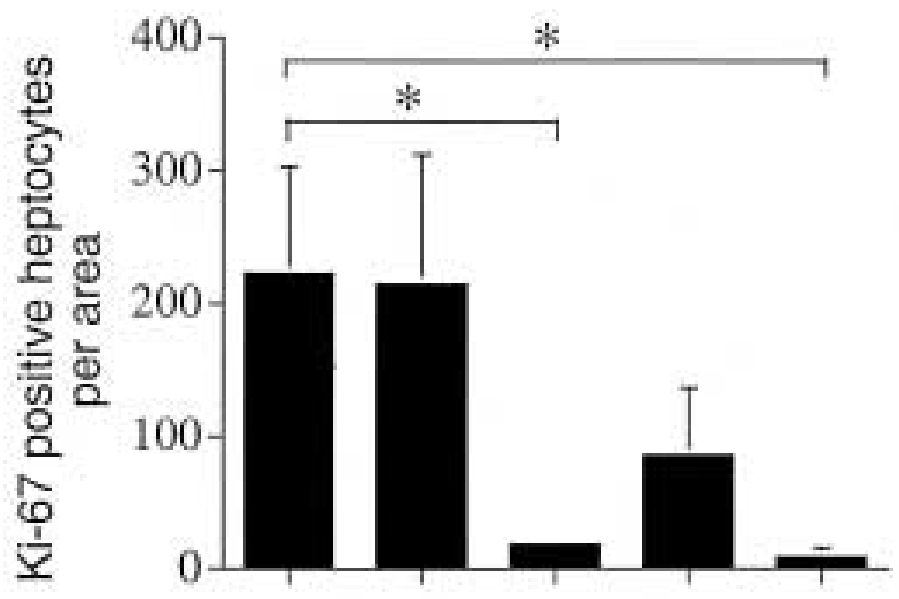

\section{Vectors}

AdJM17 $\triangle E 1$

AdhAAT $\triangle E 1$

AdSTK109

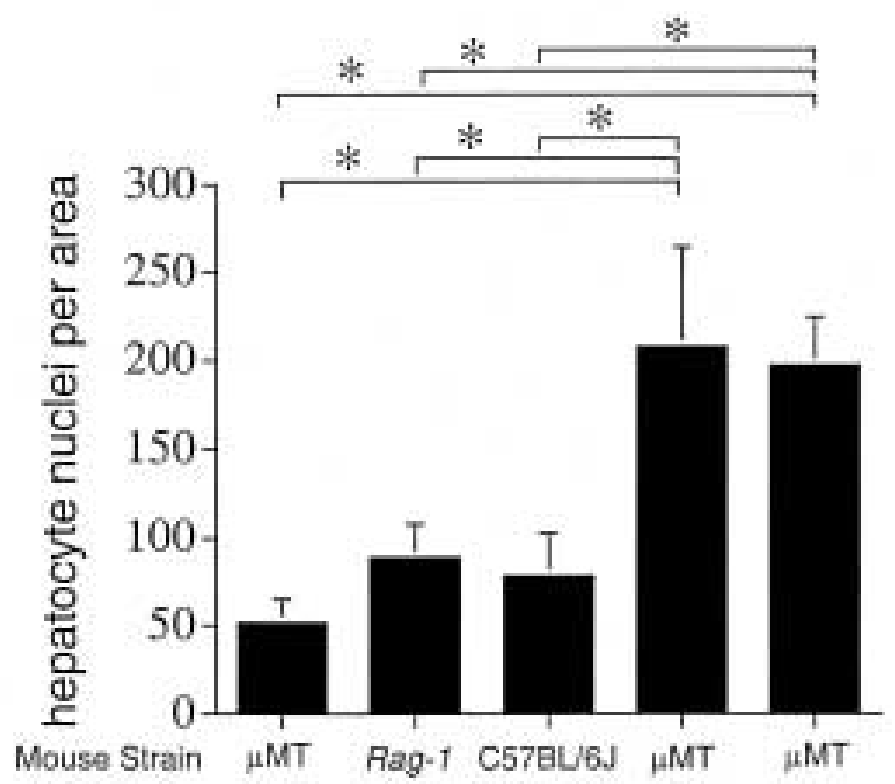

Adßgal $\Delta E 1$

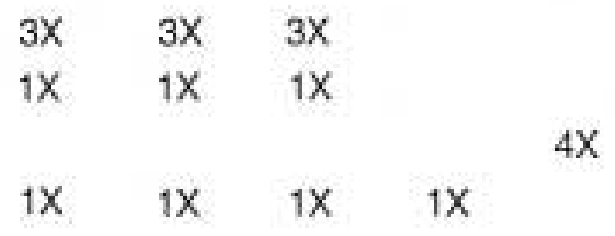

Fig. 3. Continued

levels in naive $\mu \mathrm{MT}$ or $\mathrm{C} 57 \mathrm{BL} / 6 \mathrm{~J}$ mice that had not received previous adenovirus doses. The two groups of $\mu \mathrm{MT}$ mice receiving either three doses of reporterless vector or three different vectors demonstrated 2 -fold higher levels of hAAT at day 3, compared with naive $\mu \mathrm{MT}$ or C57BL/6J mice (Fig. 2B). However, the levels of hAAT fell rapidly in the pretreated mice such that, by day 7, the levels of hAAT were similar among all the groups (Fig. 2B).

Because there was no difference between the two groups of $\mu \mathrm{MT}$ mice receiving just the reporterless vector and mice receiving the three different vectors, the change in transgene expression in previously treated animals was due to the presence of the viral backbone and not due to expression of reporter genes. Importantly, in pretreated mice compared with naive mice, multiple dosing with first-generation vector did not eliminate the ability to express hAAT after delivery of AdhAAT $\Delta$ El and did not lead to total loss of expression over time. 


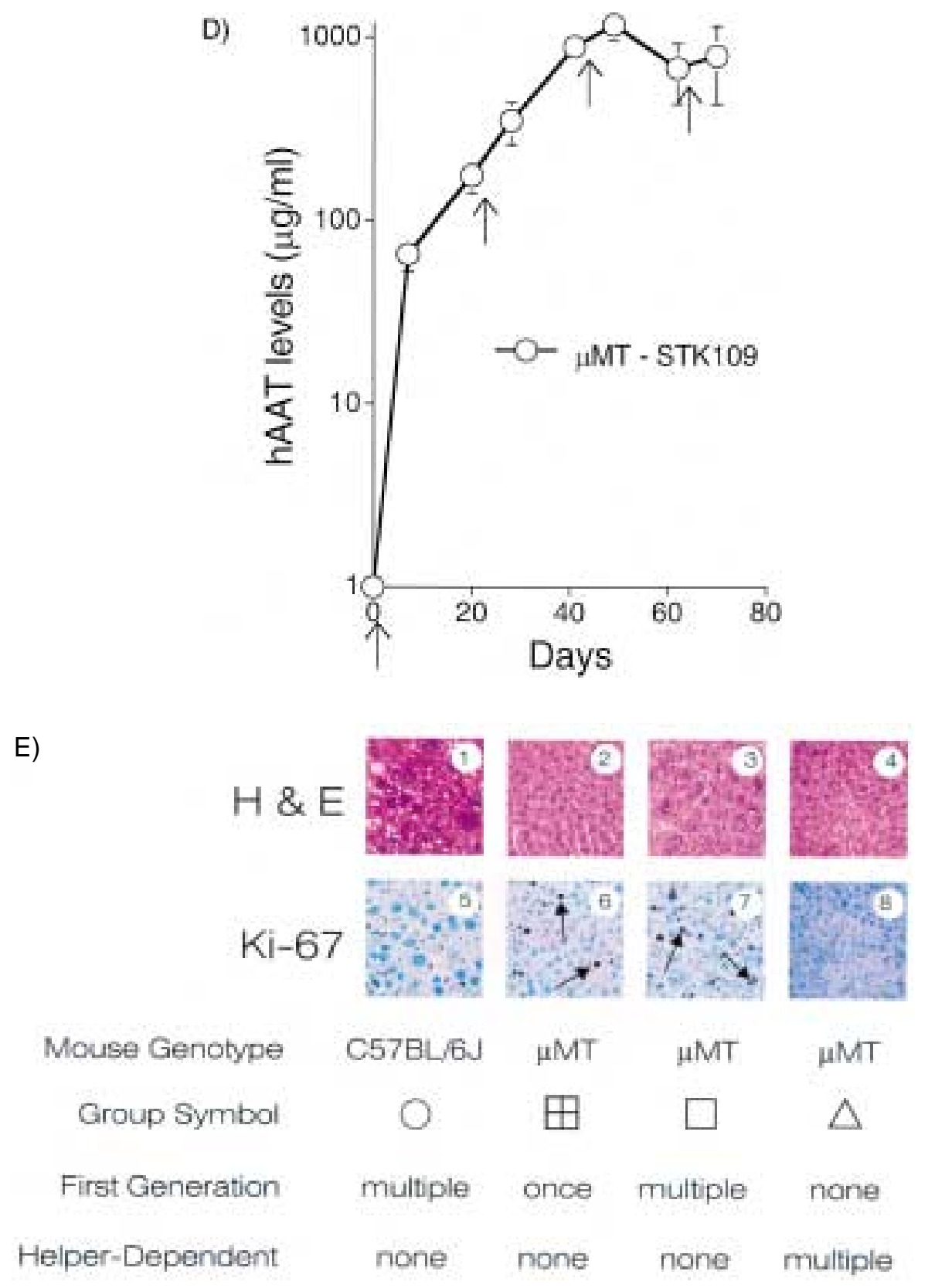

Fig. 3. Continued

This was apparent even though there was a change in expression kinetics and total hAAT levels tended to be lower throughout the experiment after day 7 in pretreated mice (statistically significant only at day 56). Thus, hAAT was still measurable in all groups, albeit at low levels, 68 days after administration of AdhAAT $\Delta E 1$. These results argue that any Tcell responses to vectors that developed after the initial administration of vectors were incapable of completely eliminating infected cells after subsequent doses.
To gain more information about the altered expression kinetics initially observed, the same animals were again dosed with AdJM17DEl, as indicated in Figure $2 \mathrm{~A}$, followed by a final dose of AdhAAT $\triangle E$ l. Then, hAAT levels were compared with levels in new naive mice. As in the initial evaluation, hAAT levels in the serum were higher at early times in mice that had been previously exposed to adenoviral vectors (Fig. 2C). At days 83 and 89 (days 1 and 3 after the final injection of AdhAAT $\Delta E 1)$, hAAT levels were elevated in all groups of mice pre- 
viously treated with vectors, compared with naive mice (Fig. 2C). In fact, at day 1 after administration, hAAT levels were easily measured in all pretreated mice, but were not detectable in the naive mice. By day 7 (day 89 in Fig. 2C) after this injection, levels in pretreated mice had fallen to be similar mice that had not been treated previously. These results suggest that pretreating $\mu \mathrm{MT}$ mice with multiple doses of first-generation vectors somehow led to robust, early expression of hAAT with subsequent doses when compared with naive animals. The reason for the increased transgene expression is unknown and determining it will require additional experimentation. Animals in this experiment were sacrificed 7 days after the final AdhAAT $\Delta$ El injection for histological analysis of the livers. Evaluation of the liver sections suggested that repeated administration of adenovirus vectors increased the toxicity of subsequent administrations and an experiment designed to more specifically evaluate hepatocyte toxicity was conducted.

Multiple Administration of Vectors Increases Toxicity with First-generation Vectors

We examined liver toxicity of multiple injections of a first generation adenoviral vector according to the protocol outlined in Figure 3A. For this experiment an additional genotype of animals, Rag-1, that are deficient in both B and $\mathrm{T}$ cells, was added. By comparing responses in $\mu \mathrm{MT}$ and Rag-1 animals, we sought to determine the contribution of $\mathrm{T}$ cells to any observed effects. Immunocompetent C57BL/6J mice heterozygous for Rag-1 (+/-) that were generated during breeding of the Rag-1 animals served as one control group; in these control mice, development of neutralizing antibodies prevented effective infection after the first administration. Toxicity to hepatocytes was evaluated during the course of the experiment by analyses of levels of liver enzymes and, at the end of the experiment, by histological analysis of liver for evaluation of hepatocyte proliferation and hypertrophy.

Liver function tests (LFT), including AP, ALT, and AST, were performed 1 day prior to and 7 days after each dose of vector (Fig. 3A). Throughout the course of evaluation, all LFT values remained within the normal range for C57BL/6J animals (Fig. 3A) even though single, higher doses of first-generation vectors routinely cause increased LFT values in C57BL/6J mice (data not shown). However, LFT values started to increase in both $\mu \mathrm{MT}$ and Rag-1 mice after the second dose of vector, compared with the first dose, and for the most part, continued to increase after each subsequent dose (Fig. 3A). In C57BL/6J control animals, the vector did not transduce the hepatocytes after the initial injection, because of neutralizing antibodies, and liver enzymes were not elevated after subsequent doses. However, in the immunodeficient animals, repeat administrations reach the liver where they can contribute to hepatotoxicity. As increases in LFT's were seen in both immunodeficient models, these results suggested that toxicity was not due to T-cell responses alone.

It was not clear from the data whether the increased levels of toxicity observed were simply due to a cumulative effect of increasing vector dose in cells previously affected by vector or if the vector itself became more toxic per infectious unit after repeated administration. Higher single doses of first-generation vector can lead to elevations in liver enzymes. In a separate experiment (not shown), $\mu \mathrm{MT}$ mice receiving a single dose of $3 \times 10^{9} \mathrm{PFU} /$ mouse of AdJM17 $\Delta \mathrm{E} 1$ (three times the single doses used in the experiments described here) developed elevated liver enzymes that reached a maximum level 7 days after administration. Peak levels were $154( \pm 87), 542( \pm 170)$, and $254( \pm 107)$ IU/liter for ALT, AP, and AST, respectively $(n=4)$ after a single, high administration. These values were similar to those observed in Rag-1 mice after the third injection, but not as high as those reached in the $\mu \mathrm{MT}$ mice. In $\mu \mathrm{MT}$ mice, a comparison of values 7 days after injection of the third of 3 doses to values 7 days after a single, higher dose indicated a significant increase in levels of ALT $(p=0.0366)$ and AP $(p=0.0045)$, but not of AST $(p=0.2762)$ in multiply dosed animals. Although not entirely conclusive, these data suggested the possibility that, at least in the presence of functioning $T$ cells, a given dose of first generation vector divided in three injections separated by 3 weeks was more toxic than the same dose given in an initial single dose. The effects may be less or more pronounced at lower or higher doses, respectively; this is an issue that will require additional experiments to resolve.

As in the previous experiment shown in 
Figure 2, hAAT levels were significantly higher at day 3 after AdhAAT $\Delta \mathrm{E} 1$ administration in $\mu$ MT mice previously treated with vector, compared with control $\mu \mathrm{MT}$ mice receiving only one dose of AdhAAT $\Delta$ El (Fig. 3B). By day 7, hAAT values were again similar between the two groups. The higher expression at day 3 was present, but was not as prominent, in Rag-1 mice.

To evaluate other signs of toxicity and to gain further insight into expression, $\mu \mathrm{MT}$, Rag-1, and C57BL/6J mice (the first three groups described in Fig. 3A) were given an additional dose of $\mathrm{Ad} \beta \mathrm{gal} \Delta \mathrm{El}$ at 3 weeks after the fourth injection (the injection of Ad$\mathrm{hAAT} \Delta \mathrm{E} 1)$. A new group of naive $\mu \mathrm{MT}$ mice was also treated with the $A d \beta \operatorname{gal} \Delta \mathrm{El}$ vector to serve as a control for a single injection. The mice were sacrificed after 3 days and the livers were examined histologically. No obvious differences in $\beta$-gal expression were observed between naive $\mu \mathrm{MT}$ control mice and $\mu \mathrm{MT}$ mice that were treated with multiple doses. However, signs of toxicity, as measured by differences in hepatocyte proliferation and hypertrophy, were observed (Fig. 3C and 3E). The number of proliferating hepatocytes, as evaluated by the cell proliferation marker Ki-67, was higher in both $\mu \mathrm{MT}$ and Rag-1 mice that had received previous administration of vectors, compared with the C57BL/6J control mice ( $p=$ $0.0139)$. The number of prolif. cells was somewhat higher than in the naive $\mu \mathrm{MT}$ mice (not significant; $p>0.05$ ) (Fig. 3C, top panel; Fig. $3 \mathrm{E}$, panels 5-7). Administration of a single dose of first-generation vector can itself lead to some hepatocyte proliferation. This was indicated by an small increase in Ki-67 positive cells from naive $\mu \mathrm{MT}$ mice, compared with multiply treated C57BL/6J mice (Fig. 3C and 3E, panels 5 and 6). Hepatocyte transduction of $\operatorname{Ad} \beta$ gal $\Delta \mathrm{El}$ did not occur in $\mathrm{C} 57 \mathrm{BL} / 6 \mathrm{~J}$ because of neutralizing antibodies from previous doses (not shown). This result is consistent with those of other studies demonstrating early cell proliferation after a single dose that disappears with time (34). Although the difference in $\mathrm{Ki}$ 67 staining between the mice that received previous administration and the naive $\mu \mathrm{MT}$ mice was not significant $(p>0.05)$, we believe that this may reflect the small sample size in this experiment. Hepatocyte hypertrophy, which was measured by counting the number of nuclei in a given area (the lower the number of nuclei, the greater the degree of hypertrophy) also oc- curred in previously treated animals. Interestingly, the same degree of hypertrophy was measured in immunocompetent C57BL/6J animals in which hepatocyte transduction occured only once during the initial treatment (Fig. 3C, bottom panel and Fig. 3E, panels 1 and 3). The data suggested that the toxicity, as measured by hepatocyte hypertrophy, resulted from a single exposure of hepatocytes to a first-generation vector. The data from the C57BL/6J immunocompetent mice and the naive $\mu \mathrm{MT}$ mice suggested that the initial exposure may have its effect over a long period of time ( 12 weeks in this experiment) and that this effect was not seen early after a single administration. These results are consistent with previous data showing an increase in polymorphism of cell bodies and nuclei, necroses and lipid accumulation in hepatocytes at 12, compared with 2, weeks after administration of the first-generation vector (37) and with data showing hepatocyte hypertrophy at 21 , but not at 3, days after administration (34). Additional studies are needed to determine the duration of this effect in animals treated with first-generation vectors. As with cell proliferation, the increase in hepatocyte size was not dependent on the presence of $T$ cells, inasmuch as both responses occurred to a similar degree in Rag-1 and $\mu$ MT animals.

\section{No Toxic Effects Were Measured after Multiple Administrations of Helper-dependent Vector AdSTK109}

To evaluate the effect of readministration of the newly developed helper-dependent vector, AdSTK 109, an experiment similar to the one conducted with first generation vectors was performed. AdSTK109 was administered four times at 3-week intervals to $\mu \mathrm{MT}$ mice and liver enzyme analysis was conducted, along with hAAT assay, at times indicated in Figure 3A. Mice were sacrificed 7 days after the final administration of vector to evaluate the livers histologically for hepatocyte proliferation and hypertrophy. Liver enzymes remained close to preinjection values throughout the entire experiment, indicating that these treatments were nontoxic, compared with firstgeneration vectors, where enzyme levels began to increase after the second dose (Fig. 3A). Levels of hAAT were considerable, reaching a maximum of about $1 \mathrm{mg} / \mathrm{ml}$ after the third dose of vector (Fig. 3D). In contrast to results seen after multiple doses of first-generation vectors, 
histological analysis of livers after four doses of AdSTK109 showed very few proliferating hepatocytes and no hepatocyte hypertrophy (Fig. 3c and 3e, panels 4 and 8). These results were consistent with previous data indicating that this vector was less toxic than firstgeneration vectors $(16,37)$. The results also suggested that the toxicity associated with readministration of first-generation vectors was dependent on the expression of viral genes and not simply on cellular entry of the vector particles, as AdSTK109 was also an Ad5-based vector.

\section{Discussion}

These experiments utilized mouse models deficient for the production of B cells to evaluate the effects of repeated administration of adenoviral vectors on expression and toxicity. The B-cell-deficient mice ( $\mu$ MT) used in these experiments are deficient in the membrane-spanning region of immunoglobulin $\mu$ heavy chain (53). This deficiency leads to a blockage of B cells during development at the pre-B-cell stage, which effectively eliminates the production of antibodies in these mice. However, these mice have been widely evaluated with respect to their T-cell function and there is considerable evidence that $\mathrm{T}$-cell function remains intact (54). The $\mu \mathrm{MT}$ mice have normal numbers of splenic $\mathrm{CD} 4^{+}$and $\mathrm{CD} 8^{+} \mathrm{T}$ cells that can be successfully primed (54). The $\mu \mathrm{MT}$ mice develop delayed-type hypersensitivity responses (67), are able to clear viral and bacterial infections by virtue of $\mathrm{CD}^{+}$and $\mathrm{CD} 8^{+} \mathrm{T}$ lymphocyte responses, reject xenografts (73), develop efficient T-cell memory against viruses (70), and have normal T-cell memory (70). The $\mu \mathrm{MT}$ mice were used in these experiments as a model to study multiple rounds of vector administration in the presence of T-cell function.

The results indicate that expression of transgenes following multiple administrations of first-generation adenoviral vectors is possible if neutralizing antibodies can be eliminated from the host. In addition, even though there were some changes in the kinetics of transgene expression after repeated administration of first-generation vectors, transgene expression was maintained for at least 6 weeks in these animals. This result suggests that the presence of T-cell-mediated immune responses against viral proteins that would be expected to de- velop after the initial exposure to vector will not necessarily or significantly limit the duration of expression from subsequent doses of vectors. In this regard, the results are similar to previous findings that long-term expression of transgenes is possible in mice if immune responses against the transgene can be eliminated $(12,19,74,75)$. Of particular relevance is the previously reported observation that C57BL/6 mice had prolonged expression of the hAAT transgene despite the presence of robust, specific, cellular immune responses against adenovirus-specific proteins (74).

That stated, repeated administration does not appear to be totally without effect with regards to transgene expression. The experiments reported here indicate that previous administration of first generation vectors can alter the kinetics of expression from subsequent doses. One and 3 days after intravenous delivery of the first-generation vector AdhAAT $\Delta \mathrm{E} 1$, levels of hAAT were higher in $\mu \mathrm{MT}$ mice previously treated with first-generation vectors, compared with naive mice. Levels then fell rapidly, so that by 7 days, they were similar to levels obtained in control mice and, subsequently, dropped to slightly below levels in control mice.

The reason for the initial relative increase in transgene expression is not clear and will require further evaluation. It is possible that this phenomenon is due to an increase in the susceptibility of target cells, in this case hepatocytes, to infection, perhaps by upregulation of genes involved in adenoviral uptake or by changes in hepatic or vascular architecture allowing easier access of vector particles to hepatocytes. The rapid drop in expression could then be accounted for by rapid loss of infected cells due to direct vector toxicity. It is known that high doses of vectors can be directly toxic to cells and may lead to relatively rapid loss of transgene expression (12). The increased level of hepatocyte proliferation (as measured by immunohistochemical staining for cell proliferation marker, Ki-67) and the increased hepatotoxicity (as measured by increased liver enzymes in the serum) that were noted in the mice from the experiments reported here would support this hypothesis. Alternatively, the higher initial levels and the rapid drop of transgene expression observed after repeated administration could be explained by an increase in infection of cells other than hepatocytes, perhaps macrophages, Kupffer cells or 
other cells that became activated as a result of previous exposure to the vectors. The possibility that the altered kinetics could be explained by changes in the activity of the promoter driving the transgene should also be considiered. Regardless of the reason(s) for the observed effects, the results indicate that, for clinical considerations, previous injections of first-generation vectors can have significant and not always predictable effects on expression induced by subsequent treatments.

In addition to altering expression kinetics, previous administrations of first-generation vectors tended to increase the toxicity of subsequent administrations, as indicated by elevations in liver enzymes. Administration of a single dose of first-generation vectors at the doses used in these experiments did not lead to an appreciable rise in liver enzymes; whereas, administration of subsequent doses led to a rise in all enzymes in both $\mu \mathrm{MT}$ and Rag-1 mice. Rag-1 mice are deficient in the recombination activation gene 1 , which causes an arrest of $\mathrm{B}$ - and T-cell differentiation, leading to absence of mature B and T cells (61). Although the data comparing the two groups of mice suggest that $\mathrm{T}$ cells may play a role in attenuating certain specific aspects of the toxicity observed, in its entirety, we conclude that development of hepatocyte toxicity, as observed in these experiments, was not dependent on T-cell functions. Toxicity from first-generation vectors in Rag-1 animals has been reported elsewhere (37). We favor the interpretation that the toxicity is most likely due to direct cytotoxic effects of viral proteins, although the activity of Kupffer cells or other immune cells not absent in Rag-1 mice may also be involved.

In contrast to toxicity as measured by liver enzymes and cell proliferation, an increase in hepatocyte size (hepatocye hypertrophy) is not only induced by multiple doses of vectors, but occurs even after a single vector dose. The hypertrophy that develops is relatively long-lived (at least 12 weeks) and we believe that this is an important response that deserves further characterization. The development of hepatocyte hypertophy after a single dose of vector is interesting in light of a recent report demonstrating that first-generation adenoviral vectors containing the $\mathrm{E} 4$ region can lead to $\mathrm{G}_{2}$ growth arrest in immortalized human bronchial epithelial cells (76). In that report, infection with first-generation vectors produced aneuploidy and polyploidization as a result of cell division without mitosis and altered levels of cyclin gene expression. Similar effects may be occurring in transduced hepatocytes. The development of hypertrophy of hepatocytes after adenoviral vector administration has not been widely appreciated, despite the fact that intravenous injection of first-generation adenoviral vectors has been extensively studied. We hypothesize that in animal models where transduced cells are not eliminated by the immune system, such as in our model of C57BL/6J mice infected with hAAT adenoviral vectors, the effects of low-level viral gene expression from first-generation vectors over long periods of time lead to the changes in hepatocyte morphology that we observed. These changes would not be seen in animal models where transduced cells are completely eliminated by the immune system. Consequently, these longterm effects on hepatocytes have been underappreciated and they may have unanticipated consequences.

In contrast to first-generation vectors, multiple administrations of AdSTK109, a helperdependent vector that contains no adenoviral coding sequences (37), did not cause hepatocyte toxicity. In animals treated with AdSTK 109 four times, over a period of 12 weeks, at the doses used in these studies, there was no increase in liver enzymes nor was there an increase in hepatocyte proliferation or hypertrophy. This vector previously showed reduced toxicity, compared with first-generation vectors, after a single administration $(16,37)$. In an earlier report, high doses of the helperdependent AdSTK109 vector did not cause increased liver enzymes or acute hepatic injury, in contrast to effects with much lower doses of first-generation vector (16). Although it is difficult to directly compare the doses of firstgeneration and helper-dependent vectors due to the inherent difficulties with determining infectious units in a helper-dependent preparation, the results reported here certainly support the previous findings indicating a significant safety advantage for helper-dependent vectors, compared with first-generation vectors. A separate helper-dependent vector expressing a leptin transgene also was reported to exhibit enhanced safety, compared with firstgeneration vectors $(38,39)$. The results demonstrated here provide additional evidence for the safety of the helper-dependent vector. Furthermore, because AdSTK 109 is packaged in an intact Ad5 capsid that is indistinguishable from 
the capsid of the first-generation vectors (59), the data imply that the toxicity seen after multiple administrations of first-generation vectors is related to the presence of adenoviral genes expressed in infected cells, rather than to the presence of the viral capsid or to the process of vector entry into cells. It will now be necessary to compare the toxicity of the helper-dependent vectors to first-generation vectors in other tissues, such as the lung, where the mechanisms that lead to toxicity might be different than those observed in the liver.

Although at the present time it is not possible to give multiple doses of adenoviral vectors to a single immunocompetent individual due to the development of neutralizing antibodies, the use of alternative serotypes (48-50) or transient immunosuppression (41-46) may eventually allow successful readministration. Success has been achieved in preparing Ad 2based helper-dependent vectors (submitted manuscript, R. Parks, et al.). The experiments described here highlight the importance of considering both previous naturally occurring Ad5 infections and previous administration of vectors when evaluating readministration of adenoviral vectors for clinical use. Patients who already have been primed by previous natural infection or by administration of firstgeneration vectors might show an altered response to subsequent administrations of vectors, which may be manifested by increased toxicity and altered expression of the therapeutic gene. However, these experiments are encouraging in that long-term transgene expression was possible even after several previous exposures to vector. This suggests that T-cell responses against the helper-dependent vector may prove to be negligible, even though other reports clearly indicate that they can be present and important in some models with earlier generations of vectors (7-10). Of course, T-cell responses to vector proteins may prove to be more important in other organisms or even in other strains of mice. The experiments described here were all conducted in C57BL/6J background, where previous experience demonstrated the ability to maintain long-term expression after a single administration $(12,77)$. Finally, these experiments highlight yet another advantage of the helper-dependent system, which appears to be devoid of the complications of readministration to hepatocytes, as seen with the first-generation vectors in these experiments.

\section{Acknowledgments}

The authors thank Yufen Wang and Rizwan Velji for excellent technical assistance, Janet Quinones for performing the sectioning and histochemical stains, and the Baylor College of Medicine Gene Vector Production Core Laboratory, especially Dr. Estuardo Aguilar-Cordova and Cassandra Nyberg-Hoffman, for production of the first-generation vectors used in these experiments. This work was supported by grants from the Cystic Fibrosis Foundation (S882, F806, and F984), the NIH (HL5 1754). F. G. and R. P. are also supported by the Natural Sciences and Engineering Research Council, the Medical Research Council, and the National Cancer Institute of Canada. N. M. is a recipeint of a fellowship from the Ministerio de Educacion y Cultura (Spain).

\section{References}

1. Graham FL, Prevec L. (1992) Adenovirus-based expression vectors and recombinant vaccines. In: Ellis RW (ed.). Vaccines: New Approaches in Immunological Problems. Butterworth-Heinemann, Boston, MA. pp. 363-390.

2. Berkner KL. (1988) Development of adenovirus vectors for the expression of heterologous genes. BioTechniques 6: 616-629.

3. Graham FL, Prevec L. (1995) Methods for construction of adenovirus vectors. Mol. Biotech. 3: 207-220.

4. Kaplan JM, St. George JA, Pennington SE, et al. (1996) Humoral and cellular immune responses of nonhuman primates to long-term repeated lung exposure to Ad2/CFTR-2. Gene Therapy 3: 117-127.

5. Kozarsky KF, McKinley DR, Austin LL, et al. (1994) In vivo correction of low density lipoprotein receptor deficiency in the Watanabe heritable hyperlipidemic rabbit with recombinant adenoviruses. J. Biol. Chem. 269: 13695-13702.

6. Yei S, Mittereder N, Tang K, O'Sullivan C, Trapnell BC. (1994) Adenovirus-mediated gene transfer for cystic fibrosis: quantitative evaluation of repeated in vivo vector administration to the lung. Gene Therapy 1: 192-200.

7. Yang Y, Ertl HCJ, Wilson JM. (1994) MHC class I-restricted cytotoxic $\mathrm{T}$ lymphocytes to viral antigens destroy hepatocytes in mice infected with El-deleted recombinant adenoviruses. Immunity 1: 433-442.

8. Yang Y, Nunes FA, Berencsi K, et al. (1994) Cellular immunity to viral antigens limits E1deleted adenoviruses for gene therapy. Proc. Natl. Acad. Sci. U.S.A. 91: 4407-4411. 
9. Yang Y, Li Q, Ertl HCJ, Wilson JM. (1995) Cellular and humoral immune responses to viral antigens create barriers to lung-directed gene therapy with recombinant adenoviruses. J. Virol. 69: 2004-2015.

10. Yang Y, Su Q, Wilson JM. (1996) Role of viral antigens in destructive cellular immune responses to adenovirus vector-transduced cells in mouse lungs. J. Virol. 70: 7209-7212.

11. Dai Y, Schwarz EM, Gu D, et al. (1995) Cellular and humoral immune responses to adenoviral vectors containing factor IX gene: tolerization of factor IX and vector antigens allows for longterm expression. Proc. Natl. Acad. Sci. U.S.A. 92: 1401-1405.

12. Morral N, O'Neal WK, Zhou H, Langston C, Beaudet A. (1997) Immune responses to reporter proteins and high viral dose limit duration of expression with adenoviral vectors: comparison of E2a wild type and E2a deleted vectors. Hum. Gene Ther. 8: 1275-1286.

13. Tripathy SK, Black HB, Goldwasser E, Leiden JM. (1996) Immune responses to transgeneencoded proteins limit the stability of gene expression after injection of replication-defective adenovirus vectors. Nat. Med. 2: 545-550.

14. Van Ginkel FW, Liu C, Simecka JW, et al. (1995) Intratracheal gene delivery with adenoviral vector induces elevated systemic IgG and mucosal IgA antibodies to adenovirus and $\beta$ galactosidase. Hum. Gene Ther. 6: 895-903.

15. Michou AI, Santoro L, Christ M, et al. (1997) Adenovirus-mediated gene transfer: influence of transgene, mouse stratin ant type of immune response on persistence of transgene expression. Gene Therapy 4: 473-482.

16. Morral N, Parks RJ, Zhou H, et al. (1998) High doses of a helper-dependent adenoviral vector yield supraphysiological levels of $\alpha_{1}$-antitrypsin with negligible toxicity. Hum. Gene Ther. 9: 2709-2716.

17. Grubb BR, Pickles RJ, Ye H, et al. (1994) Inefficient gene transfer by adenovirus vector to cystic fibrosis airway epithelia of mice and humans. Nature 371: 802-806.

18. Knowles MR, Hohneker KW, Zhou Z, et al. (1995) A controlled study of adenoviral vectormediated gene transfer in the nasal epithelium of patients with cystic fibrosis [see comments]. N. Engl. J. Med. 333: 823-831.

19. Connelly S, Gardner JM, Lyons RM, McClelland A, Kaleko M. (1996) Sustained expression of therapeutic levels of human factor VIII in mice. Blood 87: 4671-4677.

20. Armentano D, Sookdeo CC, Hehir KM, et al. (1995) Characterization of an adenovirus gene transfer vector containing an E4 deletion. Hum. Gene Ther. 6: 1343-1353.

21. Yeh P, Dedieu JF, Orsini C, et al. (1996) Efficient dual transcomplementation of adenovirus El and E4 regions from a 293-derived cell line expressing a minimal E4 functional unit. J. Virol. 70: 559-565.

22. Brough DE, Lizonova A, Hsu C, Kulesa VA, Kovesdi I. (1996) A gene transfer vector-cell line system for complete functional complementation of adenovirus early regions $\mathrm{E} 1$ and E4. J. Virol. 70: 6497-6501.

23. Engelhardt JF, Ye $X$, Doranz B, Wilson JM. (1994) Ablation of E2A in recombinant adenoviruses improves transgene persistence and decreases inflammatory response in mouse liver. Proc. Natl. Acad. Sci. U.S.A. 91: 6196-6200.

24. Gao G-P, Yang Y, Wilson JM. (1996) Biology of adenovirus vectors with $\mathrm{E} 1$ and $\mathrm{E} 4$ deletions for liver-directed gene therapy. J. Virol. 70: 8934-8943.

25. Gorziglia MI, Kadan MJ, Yei S, et al. (1996) Elimination of both El and E2a from adenovirus vectors further improves prospects for in vivo human gene therapy. J. Virol. 70: 4173-4178.

26. Krougliak V, Graham FL. (1995) Development of cell lines capable of complementing E1, E4, and protein IX defective adenovirus type $5 \mathrm{mu}-$ tants. Hum. Gene Ther. 6: 1575-1586.

27. Wang Q, Jia X-C, Finer MH. (1995) A packaging cell line for propagation of recombinant adenovirus vectors containing two lethal gene-region deletion. Gene Therapy 2: 775-783.

28. Yang Y, Nunes FA, Berencsi K, et al. (1994) Inactivation of E2a in recombinant adenoviruses improves the prospect for gene therapy in cystic fibrosis. Nat. Genet. 7: 362-369.

29. Zhou H, O'Neal WK, Morral N, Beaudet AL. (1996) Development of a complementing cell line and a system for construction of adenovirus vectors with E1 and E2a deleted. J. Virol. 70: 7030-7038.

30. Engelhardt JF, Litzky L, Wilson JM. (1994) Prolonged transgene expression in cotton rat lung with recombinant adenoviruses defective in E2a. Hum. Gene Ther. 5: 1217-1229.

31. Goldman MJ, Litzky LA, Engelhardt JF, Wilson JM. (1995) Transfer of the CFTR gene to the lung of nonhuman primates with El-deleted, E2a-defective recombinant adenoviruses: a preclinical toxicology study. Hum. Gene Ther. 6: 839-851.

32. Dedieu J-F, Vigne E, Torrent C, et al. (1997) Long-term gene delivery into the livers of immunocompetent mice with El/E4-defective adenoviruses. J. Virol. 71: 4626-4637.

33. Wang Q, Greenburg G, Bunch D, Farson D, Finer MH. (1997) Persistent transgene expression in mouse liver following gene transfer with a DEl/DE4 adenovirus vector. Gene Therapy 4: 393-400.

34. O'Neal WK, Zhou H, Morral N, et al. (1998) Toxicological comparison of E2a-deleted and first generation adenoviral vectors expressin $\alpha_{1^{-}}$ 
antitrypsin after systemic delivery. Hum. Gene Ther. 9: 1587-1598.

35. Fang B, Wang H, Gordon G, et al. (1996) Lack of persistence of El- recombinant adenoviral vectors containing a temperature-sensitive E2a mutation in immunocompetent mice and hemophilia B dogs. Gene Therapy 3: 217-222.

36. Lusky M, Rittner K, Dieterle A, et al. (1998) In vitro and in vivo biology of recombinant adenovirus vectors with E1, E1/E2A or E1/E4 deleted. J. Virol. 72: 2022-2032.

37. Schiedner G, Morral N, Parks RJ, et al. (1998) Genomic DNA transfer with a high capacity adenoviral vector that has all viral genes deleted results in improved in vivo gene expression and decreased toxicity. Nat. Genet. 18: 180-183.

38. Morsy MA, Gu MC, Motzel S, et al. (1998) An adenoviral vector deleted for all viral coding sequences results in enhanced safety and extended expression of a leptin transgene. Proc. Natl. Acad. Sci. U.S.A. 95: 7866-7871.

39. Morsy MA, Caskey CT. (1998) Helper dependent adenoviral vectors-improved safety and expression. Biogenic Amines 14: 433-449.

40. Chen HH, Mack LM, Kelly R, et al. (1997) Persistence in muscle of an adenoviral vector that lacks all viral genes. Proc. Natl. Acad. Sci. U.S.A. 94: 1645-1650.

41. Kay MA, Holterman AX, Meuse L, et al. (1995) Long-term hepatic adenovirus-mediated gene expression in mice following CTLA4Ig administration. Nat. Genet. 11: 191-197.

42. Yang YP, Su Q, Grewal IS, et al. (1996) Transient subversion of cd40 ligand function diminishes immune responses to adenovirus vectors in mouse liver and lung tissues. J. Virol. 70: 6370-6377.

43. Yang Y, Trinchieri G, Wilson JM. (1995) Recombinant IL-12 prevents formation of blocking IgA antibodies to recombinant adenovirus and allows repeated gene therapy to mouse lung. Nat. Med. 1: 890-893.

44. Smith T, White BD, Gardner JM, Kaleko M, Mcclelland A. (1996) Transient immunosuppression permits successful repetitive intravenous administration of an adenovirus vector. Gene Therapy 3: 496-502.

45. Lochmuller H, Petrof BJ, Allen C, et al. (1995) Immunosuppression by FK506 markedly prolongs expression of adenovirus-delivered transgene in skeletal muscles of adult dystrophic [mdx] mice. Biochem. Biophys. Res. Comm. 213: 569-574.

46. Kolls JK, Lei D, Odom G, et al. (1996) Use of transient CD4 lymphocyte depletion to prolong transgene expression of El-deleted adenoviral vectors. Hum. Gene Ther. 7: 489-497.

47. Stein CS, Pemberton JL, Vanrooijen N, Davidson BL. (1998) Effects of macrophage depletion and anti-CD40 ligand on transgene expression and redosing with recombinant adenovirus. Gene Therapy 5: 431-439.

48. Kass-Eisler A, Leinwand L, Gall J, Bloom B, Falck-Pedersen E. (1996) Circumventing the immune response to adenovirus-mediated gene therapy. Gene Therapy 3: 154-162.

49. Mack CA, Song W-R, Carpenter H, et al. (1997) Circumvention of anti-adenovirus neutralizing immunity by administration of an adenoviral vector af an alternate serotype. Hum. Gene Ther. 8: 99-109.

50. Mastrangeli A, Harvey BG, Yao J, et al. (1996) Sero-switch adenovirus-mediated in vivo gene transfer-circumvention of anti-adenovirus humoral immune defenses against repeat adenovirus vector administration by changing the adenovirus serotype. Hum. Gene Ther. 7: 79-87.

51. Walter J, You Q, Hagstrom JN, Sands M, High KA. (1996) Successful expression of human factor IX following repeat administration of an adenoviral vector in mice. Proc. Natl. Acad. Sci. U.S.A. 93: 3056-3061.

52. De Matteo RP, Raper SE, Ahn M, et al. (1995) Gene transfer to the thymus. A means of abrogating the immune response to recombinant adenovirus. Ann. Surg. 222: 229-239.

53. Kitamura D, Roes J, Kuhn R, Rajewsky K. (1991) A B cell-deficient mouse by targeted disruption of the membrane exon of the immunoglobulin mu chain gene. Nature 350: 423-426.

54. Epstein MM, DiRosa F, Jankovic D, Sher A, Matzinger P. (1995) Successful T cell priming in B cell-deficient mice. J. Exp. Med. 182: 915-922.

55. McGrory WJ, Bautista DS, Graham FL. (1988) A simple technique for the rescue of early region 1 mutations into infectious human adenovirus type 5. Virology 163: 614-617.

56. Graham FL, Prevec L (1991) Manipulation of adenovirus vectors. In: Murray EJ (ed.) Methods in Molecular Biology: Gene Transfer and Expression Protocols. The Humana Press, Inc., Clifton, N.J, pp. 109-128.

57. Nyberg-Hoffman C, Shabram P, Li W, Giroux D, Aguilar-Cordova E. (1997) Sensitivity and reproducibility in adenoviral infectious titer determination. Nat. Med. 3: 808-811.

58. Chen L, Anton M, Graham F. (1996) Production and characterization of human 293 cell lines expressing the site-specific recombinase Cre. Somatic Cell Mol. Genet. 22: 477-488.

59. Parks RJ, Chen L, Anton M, et al. (1996) A helper-dependent adenovirus vector system: Removal of helper virus by Cre-mediated excision of the viral packaging signal. Proc. Natl. Acad. Sci. U.S.A. 93: 13565-13570.

60. Mittereder N, March KL, Trapnell BC. (1996) Evaluation of the concentration and bioactivity of adenovirus vectors for gene therapy. J. Virol. 70: 7498-7509.

61. Mombaerts P, Iacomini J, Johnson RS, et al. 
(1992) Rag-1-deficient mice have no mature B and T lymphocytes. Cell 68: 869-877.

62. Kay MA, Graham F, Leland F, Woo SLC. (1995) Therapeutic serum concentrations of human alpha-1-antitrypsin after adenoviral-mediated gene transfer into mouse hepatocytes. Hepatology 21: 815-819.

63. MacGregor GR, Mogg AE, Burke JF, Caskey CT. (1987) Histochemical staining of clonal mammalian cell lines expressing E. coli $\beta$-galactosidase indicate heterogeneous expression of the bacterial gene. Somatic Cell Mol. Genet. 13: 253365.

64. Duchrow M, Schluter C, Key G, Kubbutat, M. H. G., et al. (1995) Cell proliferation-associated nuclear antigen defined by antibody Ki-67: a new kind of cell cycle-maintaining proteins. Arch. Immunol. Ther. Exp. 43: 117-121.

65. Gerdes J, Schwab U, Lemke H, Stein H. (1983) Production of a mouse monoclonal antibody reactive with a human nuclear antigen associated with cell proliferation. Int. J. Can. 31: 13-20.

66. Guo ZS, Wang L-H, Eisensmith RC, Woo SLC. (1996) Evaluation of promoter strength for hepatic gene expression in vivo following adenovirus-mediated gene transfer. Gene Therapy 3: $802-810$.

67. Li S, Holdsworth SR, Tipping PG. (1997) Antibody independent crescentic glomerulonephritis in $\mathrm{m}$ chain deficient mice. Kidney Int. 51: 672-678.

68. Asano MS, Ahmed R. (1983) CD8 T cell memory in B cell-deficient mice. J. Exp. Med. 183: 2165-2174.

69. Jonic S, Pavic I, Polic B, et al. (1994) Anitbodies are not essential for the resolution of primary cytomegalovirus infection but limit dissemination of recurrent virus. J. Exp. Med. 179: 1713-1717.

70. Brundler MA, Aichele P, Bachmann M, et al. (1996) Immunity to viruses in B cell-deficient mice: influence of antibodies on virus persistence and on T cell memory. Eur. J. Immunol. 26: 2257-2262.

71. Williams DM, Grubbs BG, Pack E, Kelly K, Rank RG. (1997) Humoral and cellular immu- nity in secondary infection due to muring Chlamydia trachomatis. Infect. Immun. 65: 28762882.

72. Su H. (1997) Chlamydia trachomatis genital tract infection of antibody-deficient gene knockout mice. Infect. Immun. 65: 1993-1999.

73. Benda B, Karlsson-Parra A, Ridderstad A, Korsgren O. (1996) Xenograft rejection of porcine islet-like cell clusters in immunoglobulin or Fc-receptor gamma-deficient mice. Transplantation 62: 1207-1211.

74. Wadsworth SC, Zhou H, Smith AE, Kaplan JM. (1997) Adenovirus vector-infected cells can escape adenovirus antigen-specific cytotoxic Tlymphocyte killing in vivo. J. Virol. 71: 51895196.

75. Kozarsky KF, Jooss K, Donahee M, Strauss JFI, Wilson JM. (1996) Effective treatment of familial hypercholesterolaemia in the mouse model using adenovirus-mediated transfer of the VLDL receptor gene. Nat. Genet. 13: 54-62.

76. Wersto RP, Rosenthal ER, Seth PK, Eissa NT, Donahue RE. (1998) Recombinant, replicationdefective adenovirus gene transfer vectors induce cell cycle dysregulation and inappropriate expression of cyclin proteins. J. Virol. 72: 94919502.

77. Barr D, Tubb J, Ferguson D, et al. (1995) Strain related variations in adenovirally mediated transgene expression from mouse hepatocytes in vivo: comparisons between immunocompetent and immunodeficient inbred strains. Gene Therapy 2: 151-155.

78. Bett AJ, Haddara W, Prevec L, Graham FL. (1994) An efficient and flexible system for construction of adenovirus vectors with insertions or deletions in early regions 1 and 3. Proc. Natl. Acad. Sci. U.S.A. 91: 8802-8806.

79. Niwa H, Yamamura K, Mizyzaki J. (1991) Efficient selection for high-expression transfectants with a novel eukaryotic vector. Gene 108: 193200.

80. Kiwaki K, Matsuda I. (1996) Gene therapy for ornithine transcarbamylase deficiency. Acta Paediatrica Japonica 38: 189-192. 